Egypt. Acad. J. Biolog. Sci., 11(1): 1- 12 (2019)

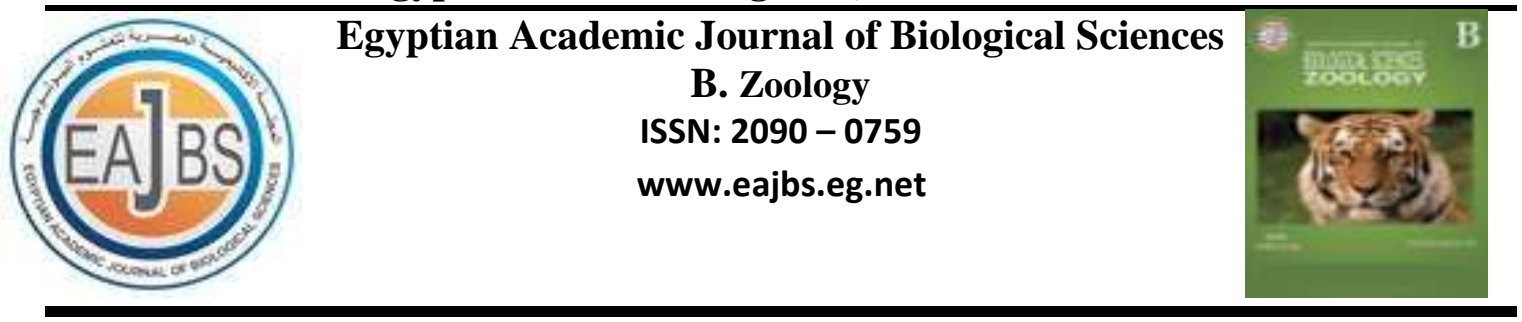

\title{
Effect of Arthropods on the Decomposition of Rat Carrions in an Aerated Environment in Spring Season in Assiut, Egypt
}

\author{
Fatma El-Zahraa A. Abd El-Aziz ${ }^{{ }^{*}}$ and Doaa M. El Shehaby ${ }^{2}$ \\ 1* Department of Zoology, Faculty of Science, Assiut University, Egypt. \\ ${ }^{2}$ Department of Forensic Medicine \& Clinical Toxicology, Faculty of Medicine, Assiut \\ University, Egypt. \\ E.Mail: F_abdelhameed @yahoo.com.
}

\section{ARTICLE INFO}

Article History

Received:1 /1/2019

Accepted:31/1/2019

Keywords:

Arthropods,

Forensic, Rat

Carrions,

Decomposition;

Assiut, Egypt.

\section{ABSTRACT}

Arthropods represent one of the most important invertebrates to arrive and colonize carrion. Objective: The present investigation aimed to determine the arthropods fauna of forensic importance that colonizes carrion in an aerated environment during Spring season in Assiut, Egypt. Methods: Experimental models rates were killed and divided into Seven groups three rats in each group. Group 1;Control, Group 2 ; Drowning, Group 3;Electro cusion, Group 4 ;Stab of the heart, Group5; Heart-abdomen stab, Group 6; Cold and Group 7; Burn. Rats were used to determine succession in an aerated area during the spring of 2018 in Assiut governorate,Egypt. Results: The present results indicated that the arthropods of forensic importance, represented by the thirteen taxa belong to phylum Arthropoda and 10 families, Family: Calliphoridae represented by Chrysomya albiceps (5\%), Family: Muscidae represented by Musca domestica (33\%), Family: Sarcophagidae represented by Sarcophaga sp.(23\%), Wohlfahrtia magnifica (22 \%) and Parasarcophaga orgyrostama( $2 \%$ ), Family: Dermestidae represented by Dermestes maculates $(1 \%)$ and Dermestes frischi(1\%), Family: Histeridae represented by Saprinus sp. (4\%), Family: Pteromalidae represented by Nasonia sp. (2\%), Family: Lycosidae represented by spider ( 3\%), Family: Pyroglyphidae represented by Dermatophagoides sp. (1 \%), Family: Cimicidae represented by Cimex lectularis (2\%) and Family: Porcellionidae represented by Porcellionides pruinosus (1 \%). Conclusion: The present investigation submitted a basis for further studies dealing with arthropods colonization of carrions.

\section{INTRODUCTION}

Arthropods species varies and the great part of all known animal species and occupied all known habitats; marine, freshwater, land and air (Yadav et al.,2017and Abd El-Aziz,2018), the number of arthropod species ( 1,170,000 - 10 million), which represented over $80 \%$ of all known living animal species (Ødegaard, 2000). Arthropods are one of the most important invertebrates to arrive and colonize a cadaver human and animals (Valdes-Perezgasga et al.2010), which includes insects, arachnids, myriapods, and crustaceans (Smith,2014 and Ortega- 
Hernández, 2016). Arthropods are found in decomposing carrion (Amendt et al,2004), so arthropods are paying a key role in medico-criminal recognition of human death (Gurafi and Mohamed , 2012). Some information can result from the study of arthropods at carrions after death( Nyasha et al., 2014).

Phylum Arthropoda in the domain of EukaInsects are invertebrates of class Insecta, insects are one of the most abundant animals on the earth (Triplehorn et al.2004), and occupied all habitats; earth, air and fresh water (Thompson,1994). James (2004) mentioned that there are about 700,000 described species and there may be more than 10 million species of insects do not describe until know. Although the number of insect species at risk of extinction( Schultz et al,2019). Insects are the most abundant living creatures that exist on the dry lands of the earth. Insects are the most abundant living creatures that exist on the dry lands of the earth.

Forensic entomologists calculate approximately post mortem interval by analyzing the development or succession of arthropods on the carrions (Matuszewski $e t$ al.,2008 and Byrd \& Castner, 2009). Forensic entomology is one of the emerging fields of forensic sciences which aids in the legal investigation and there is a need to cover of morphological identification of arthropods species especially if in the adult form of insect is not available (Zar and Huang, 2018). Identification and classification of infesting species should be done by experienced taxonomical scientists and by using different keys (Benecke 2004). Nyasha et al., (2014) and Padonou et al.(2017) conclude that there is a lack of information about forensic arthoropolgy or entomology in South Africa, Egypt, Nigeria, Cameroon, Ghana and Zimbabwe. So, the present work is an attempt to fulfill this lack and the present results of this study could be very useful for further forensic work.

\section{MATERIALS AND METHODS}

. The present investigation was carried out in Assiut University, Faculty of Medicine, Assiut Governorate, Egypt (Lying between $27^{\circ} 14^{-} \mathrm{N}$ and $31^{\circ} 11^{-} \mathrm{E}$ ), during the Spring of 2018. The site was devoid of vegetation, the climate is dry, with a mean temperature $\left(29^{\circ} \mathrm{C}\right.$ shade and $36^{\circ} \mathrm{C}$ in sun). Experimental models rates were killed and divided into Seven groups three rats in each group. Group 1;Control(271 g), Group 2 ; Drowning (286 g), Group 3; Electro cusion (338 g), Group 4 ; Stab of the heart(339g), Group5; Heart-abdomen stab (352g), Group 6; Cold (300 g) and Group 7; Burn (340 g) to be used as experimental models to simulate human cadaver decomposition. Each rat was placed in a plate and surrounded by a perforated plastic box to prevent the entry of birds and animal consumers: Passer passer domesticus, Corvus corone, Upupa epops, Egretta ibis, cats and reptiles: Mabya quinquetaeniata. The substrate of this site is formed mainly of sand and dust.

During the first two weeks after death, the carcasses were visited daily. During each visit, arthropod specimens were collected from the groups and transported to the Laboratory of the Zoology Department, Faculty of Science, Assiut University. For identification of the collecting arthropods, arthropods were placed in $72 \%$ ethanol or $10 \%$ neutral formalin for permanent storage. Half the larvae collected were preserved and the other half were reared to the adult stage using row liver in the laboratory condition for identification. 


\section{RESULTS}

\section{Identification of the Collecting Arthropods:}

In the present study, thirteen taxa were recorded. These taxa belong to phylum Arthropoda and 10 families (Table 1) and (Figs.1- 3).

1.1. Family: Calliphoridae. The adults are commonly shiny with metallic colouring, between 10 and $14 \mathrm{~mm}$ in length, often with blue, green with black thoraces and abdomens; Chrysomya albiceps (Figs.2,A\&4,A) (blow fly) represented by (5\%),.

1.2. Family: Muscidae. The adults are grey or black, with darker stripes and other patterns, medium-sized 6-9 mm long, the whole body is covered with hair ; Musca domestica (house fly) (Figs.2,B\&4,B)represented by (33\%).

1.3. Family: Sarcophagidae. The adults are small to large flies (4-23mm). Black and gray longitudinal stripes on the thorax and checkering on the abdomen and is its 3segmented antennae; Sarcophaga sp. (flesh fly) (Figs.2,C\&4,C) represented by (23\%), Wohlfahrtia magnifica (Figs.2,D\&4D) represented by (22\%) and Parasarcophaga orgyrostama (Figs.2,E\&5,A) represented by ( $2 \%$ ).

1.4. Family: Dermestidae. The adults are very small, the length is $(2-12 \mathrm{~mm})$. Their bodies are oval and convex in shape, and sometimes elongated. These are covered in hair or scales; Dermestes maculates (hide beetle) (Figs.2,F\&5,B) represented by (1\%) and Dermestes frischi (Figs.2,G\&5,C) represented by (1\%).

1.5.Family: Histeridae. The adults are shiny black or metallic green. Its shape is oval and flat. ; Saprinus sp.( clown beetles) (Figs.2,H\&5D) represented by(4\%).

1.6. Family: Pteromalidae. The adults are very small, the length is $(1-48 \mathrm{~mm})$.Its body slender to quite robust; Nasonia sp. (Figs.2,I\&6,A) represented by $(2 \%)$.

1.7. Family: Lycosidae. The body length is $(10-35 \mathrm{~mm})$ They have eight legs and eyes arranged in three rows. The adults are often dark colored, shades of tan or brown; Spider(Figs.2,J\&6,B) represented by( 3\%).

1.8. Family: Pyroglyphidae. The body length is $420 \mu \mathrm{m}$ and $320 \mu \mathrm{m}$ in width; Dermatophagoides sp.( dust mites) (Figs.2,K\&6,C) represented by(1\%).

1.9. Family: Cimicidae. The body is 5 to $7 \mathrm{~mm}$ long and $1.5-3 \mathrm{~mm}$ wide. ,reddishbrown, flat, oval, wingless and visible by the human eye and ; Cimex lectularis ( Bed bugs ) (Figs.2,L\&6,D) represented by(2\%).

1.10. Family: Porcellionidae. The body length is $5-10 \mathrm{~mm}$ (without antennae), abdomen slender clearly divides from thorax, the abdomen is narrower than the thorax, ranges from blue-violet to light orange colored, with waxy grains that makes a soft of surface and flagellum is 2-segmented; Porcellionides pruinosus (woodlouse) (Figs.2,M\&6,E) represented by $(1 \%)$.

\section{Stages of Decomposition:}

In the present investigation decomposition is divided into five stages (Fig.7).

\subsection{Fresh stage ( $0-12 \mathrm{~h})$}

This stage since the moment of death and continued until bloating. In all the seven groups no putrid odors. Families: Calliphoridae, Muscidae and Sarcophagidae were found flying around carcasses except group 7(burn).

\subsection{Bloat stage ( $12 \mathrm{~h}-3$ days)}

In the present study, all groups he carrions were completely bloated, a strong putrid odor with decomposition fluids oozing beneath the corpse. The initial colonizers were Chrysomya albiceps , Musca domestica, Sarcophaga sp., Wohlfahrtia magnifica and Parasarcophaga orgyrostama. Under the carcasses, there were numerous isopods, spiders, and beetles. 


\subsection{Active decay stage (4-6 days)}

In group 1(Control) the skin fur separation, all body surface intact and larval infestation, group 2 (Drowning) purification, open abdomen and mild larval infestation, group 3 (Electro cusion) dry body liquefied tissues in dryness form arborization, group 4 (Stab of the heart) sever putrefaction, severely liquefied tissues, intestine out abdomen and ruptured intestine pelvis, group5 (Heart-abdomen stab) liquefied tissues and intact intestine, group 6(Cold) sever infestation ,heavy larval infestation and tissue severely putrefied and group 7( Burn) just mild bloating, no ova, no larval and small ruptured left iliac fossa.

\subsection{Advanced decay stage(7-29 days)}

In all groups odors were less. Carrions were completely dehydrated with loss of weight. Dry skin was starting to separate from the bodies. Numerous insects, isopods, beetles were found. Except group 7( Burn)

\subsection{Dry (remains) stage (30-70 days)}

In all groups the fleshy tissue disappeared and odor of carrion started to fade. The rats consisted of dry skin and bone. Fewer specimens were collected from Calliphoridae, Muscidae and Sarcophagidae.

Table 1: Most abundant arthropods of forensic importance collected from on rat Carrion in a desert aerated Environment.

\begin{tabular}{|c|c|c|c|c|c|c|c|c|c|}
\hline \multirow[t]{2}{*}{ Family } & \multirow[t]{2}{*}{ Species } & \multirow[t]{2}{*}{ Days postmortem } & \multicolumn{7}{|c|}{ roups (adult arthropods no.) } \\
\hline & & & 1 & 2 & 3 & 4 & 5 & 6 & 7 \\
\hline Calliphoridae & $\begin{array}{c}\text { Chrysomya albiceps } \\
\text { (blow fly) }\end{array}$ & $(0-1),(2-4),(5-7)$ Days & 10 & 10 & 15 & 14 & 14 & 10 & $\mathbf{0}$ \\
\hline Muscidae & $\begin{array}{c}\text { Musca domestica } \\
\text { (house fly) }\end{array}$ & $(0-1),(2-4),(5-7)$ Days & 30 & 33 & 34 & 103 & 98 & 88 & $\mathbf{0}$ \\
\hline \multirow[t]{3}{*}{ Sarcophagidae } & $\begin{array}{l}\text { Sarcophaga sp. } \\
\text { (flesh fly) }\end{array}$ & $(0-1),(2-4),(5-7)$ Days & 25 & 30 & 16 & 67 & 73 & 75 & $\mathbf{0}$ \\
\hline & Wohlfahrtia magnifica & $(0-1),(2-4),(5-7)$ Days & 13 & 18 & 31 & 63 & 63 & 63 & $\mathbf{0}$ \\
\hline & $\begin{array}{r}\text { Parasarcophaga } \\
\text { orgyrostama }\end{array}$ & $(0-1),(2-4),(5-7)$ Days & 1 & 1 & 1 & 7 & 6 & 3 & $\mathbf{0}$ \\
\hline \multirow[t]{2}{*}{ Dermestidae } & $\begin{array}{c}\text { Dermestes maculates } \\
\text { (hide beetle) }\end{array}$ & $(2-4),(5-7)$ Days & 2 & 2 & 0 & 5 & 2 & 1 & $\mathbf{0}$ \\
\hline & Dermestes frischi & $(2-4),(5-7)$ Days & 2 & 5 & 3 & 4 & 1 & 2 & $\mathbf{0}$ \\
\hline Histeridae & $\begin{array}{l}\text { Saprinus sp. } \\
\text { ( clown beetles) }\end{array}$ & $(2-4),(5-7)$ Days & 7 & 9 & 3 & 9 & 11 & 9 & $\mathbf{0}$ \\
\hline Pteromalidae & Nasonia sp. & $(2-4),(5-7)$ Days & 3 & 4 & 7 & 4 & 4 & 4 & $\mathbf{0}$ \\
\hline Lycosidae & Spider & $(2-4),(5-7)$ Days & 5 & 4 & 10 & 6 & 5 & 8 & $\mathbf{0}$ \\
\hline Pyroglyphidae & $\begin{array}{l}\text { Dermatophagoides sp. } \\
\text { ( dust mites) }\end{array}$ & $(2-4),(5-7)$ Days & 2 & 2 & 2 & 2 & 5 & 2 & $\mathbf{0}$ \\
\hline Cimicidae & $\begin{array}{c}\text { Cimex lectularis } \\
\text { ( Bed bugs })\end{array}$ & $(2-4),(5-7)$ Days & 4 & 5 & 3 & 1 & 2 & 6 & $\mathbf{0}$ \\
\hline Porcellionidae & $\begin{array}{l}\text { Porcellionides pruinosus } \\
\text { (woodlouse) }\end{array}$ & $(2-4),(5-7)$ Days & 1 & 2 & 1 & 1 & 1 & 1 & $\mathbf{0}$ \\
\hline
\end{tabular}




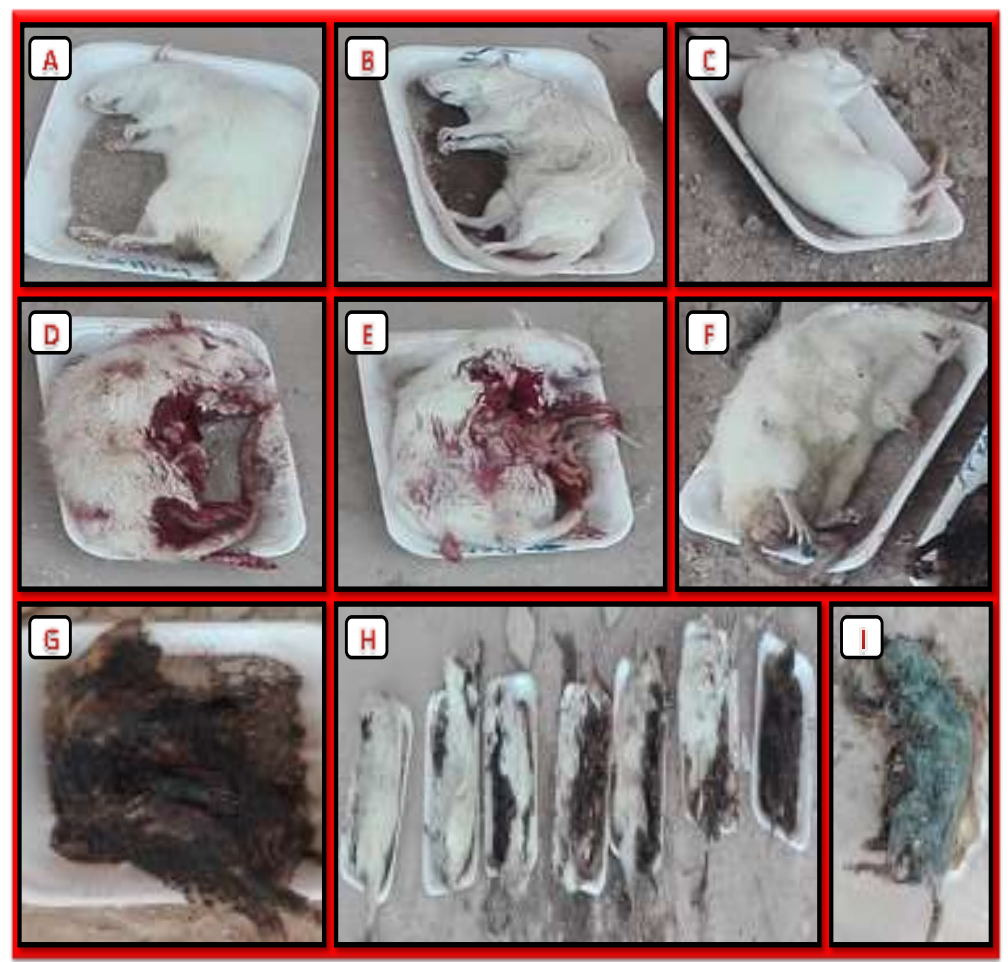

Fig. (1) :(A) Group 1; Control,(B) Group 2 ; Drowning,(C) Group 3;Electro cusion,(D) Group 4 ;Stab of the heart,(E) Group5; Heart-abdomen stab, (F) Group 6;Cold,(G) Group 7; Burn, $(\mathrm{H})$ rat carrions in active decay stage and (I) Abundance of arthropods larval stages were present all over the rat carrion.

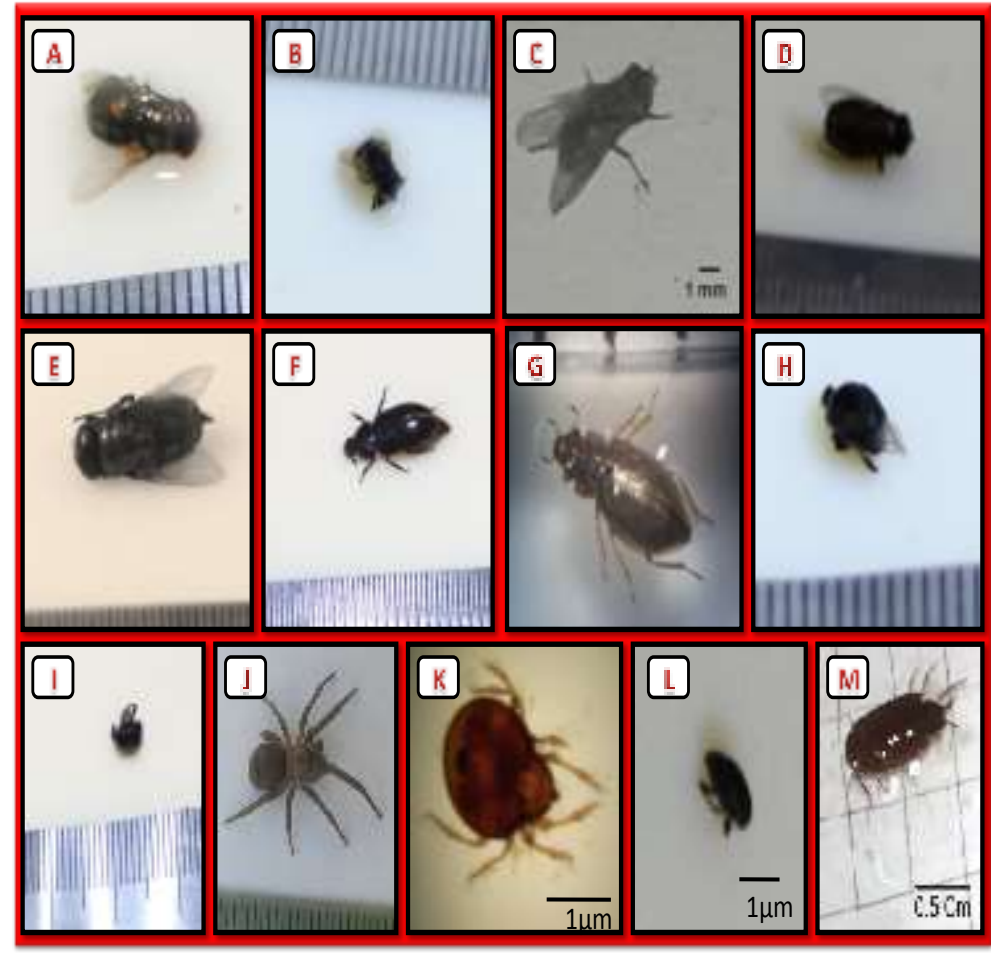

Fig. (2): (A) Chrysomya albiceps, (B) Musca domestica, (C) Sarcophaga sp.,(D) Wohlfahrtia magnifica ,(E) Parasarcophaga orgyrostama,(F) Dermestes maculates, $(\mathrm{G})$ Dermestes frischi, (H) Saprinus sp., (I) Nasonia sp., (J) $\operatorname{spider,(~K)~}$ Dermatophagoides sp., (L) Cimex lectularis and (M) Porcellionides pruinosus. 


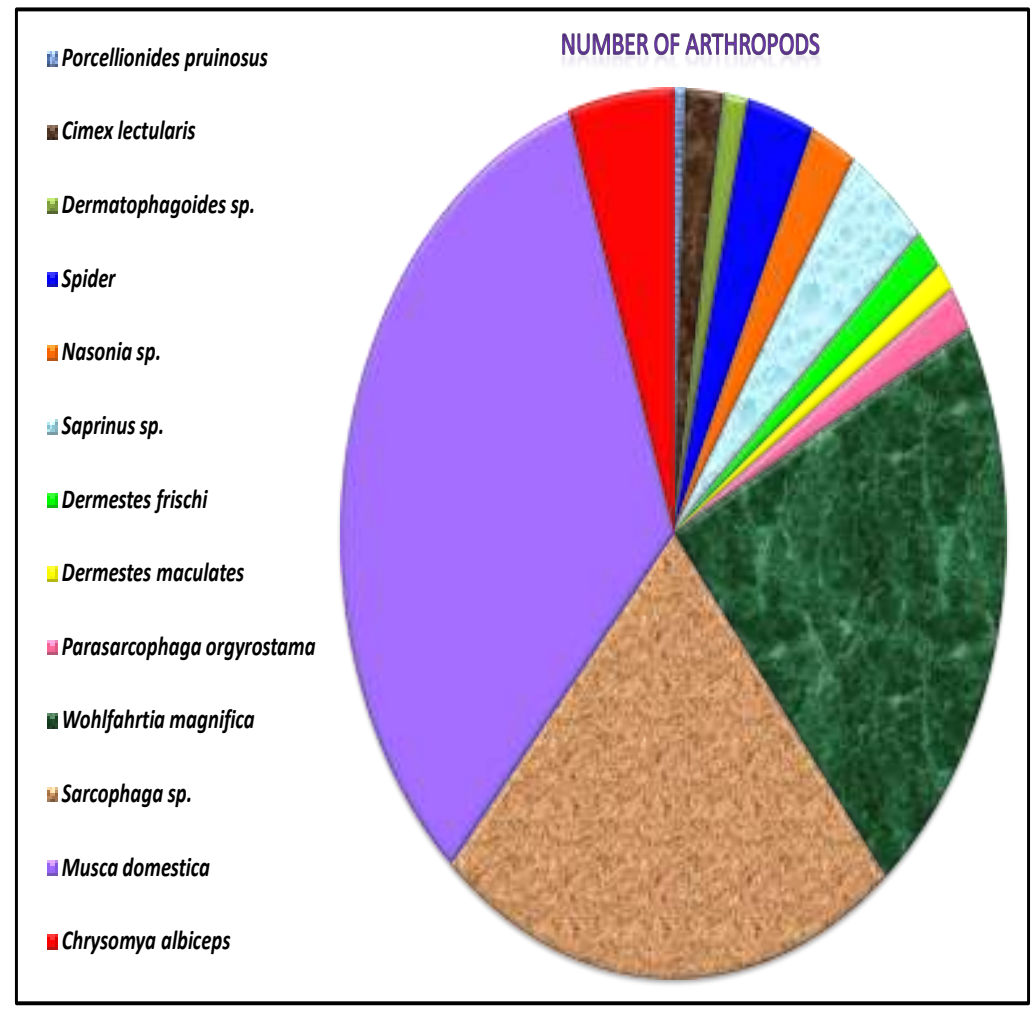

Fig. (3) : Number of arthropods from rat carrions in all seven groups.
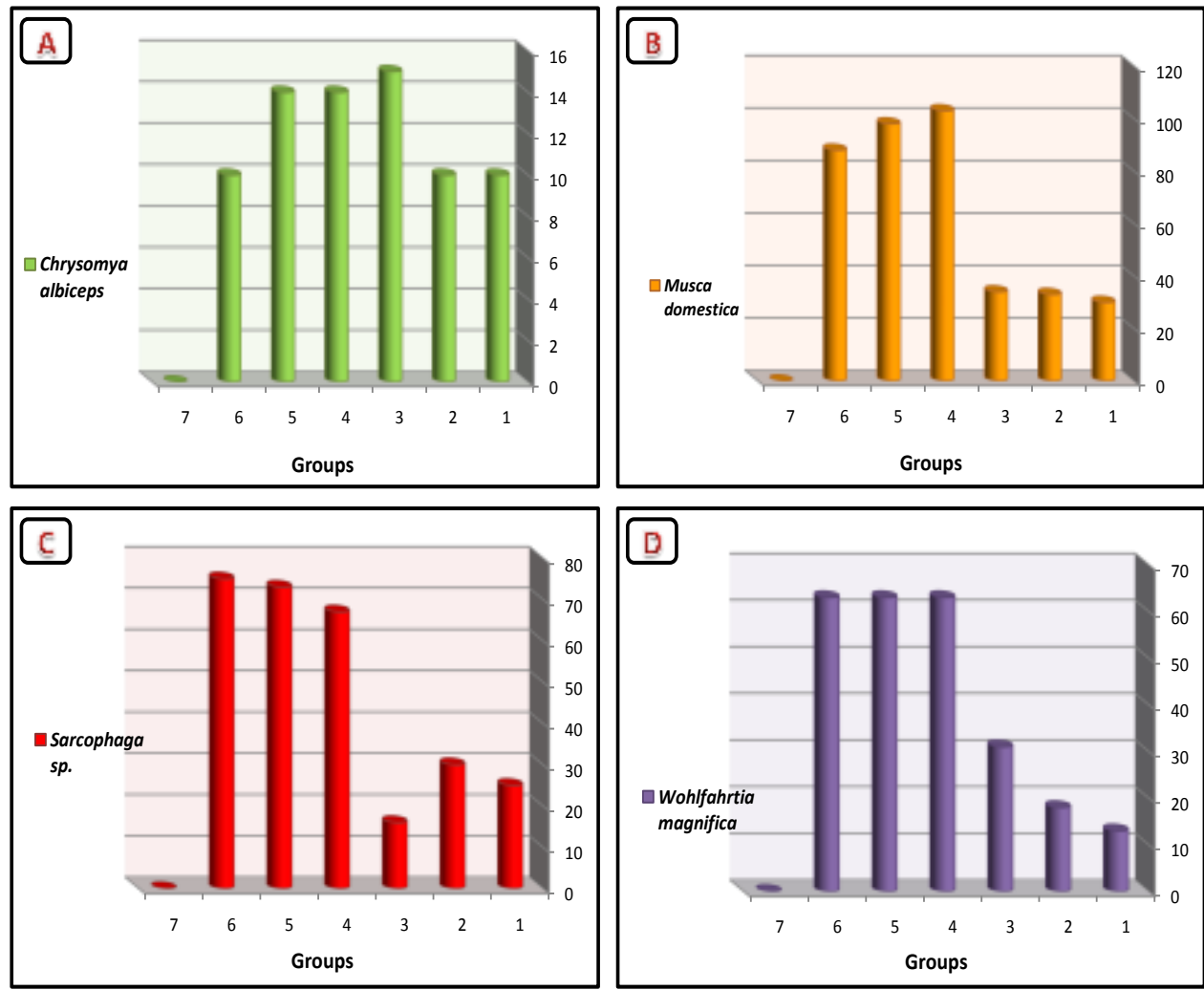

Fig. (4) : Number of arthropods from rat carrions in all seven groups, (A) Chrysomya albiceps, (B) Musca domestica, (C) Sarcophaga sp. and (D) Wohlfahrtia magnifica. 

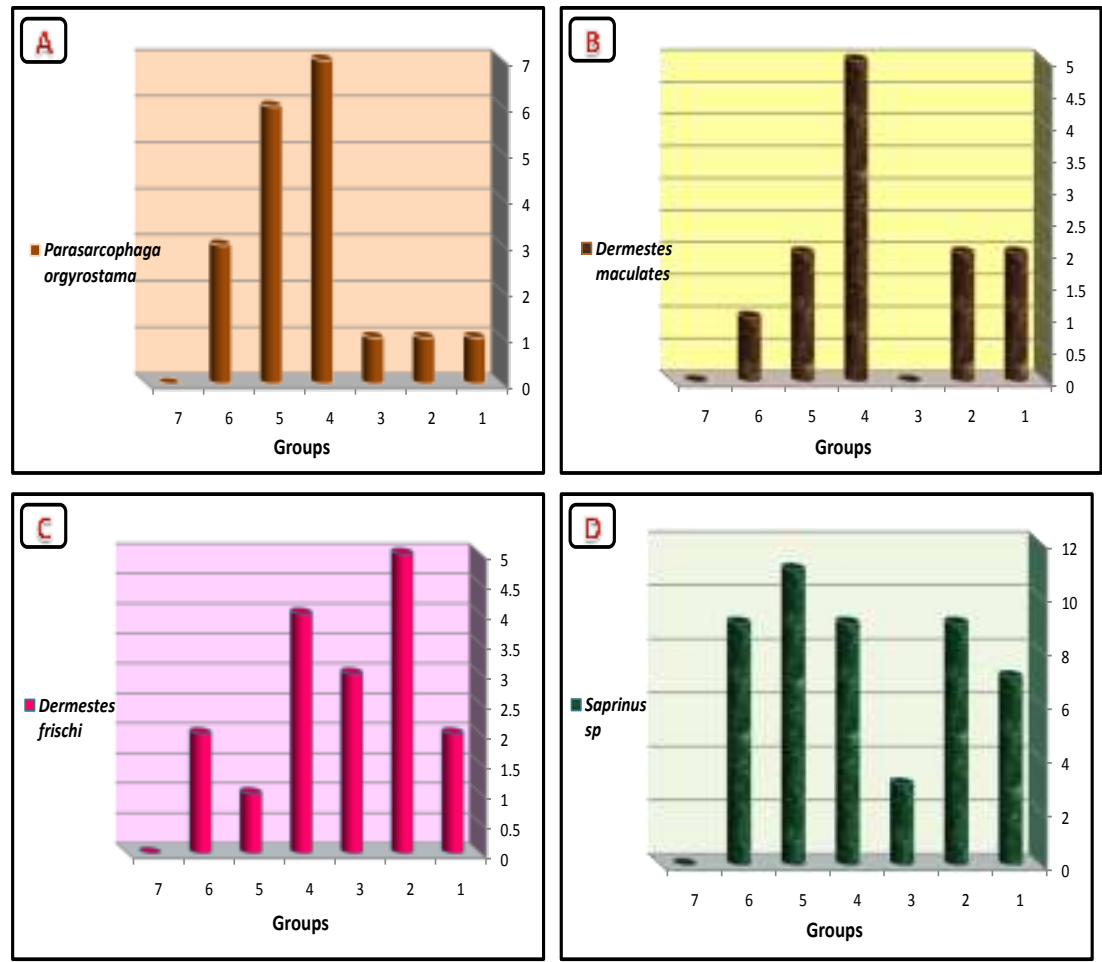

Fig. (5) : Number of arthropods from rat carrions in all seven groups, (A) Parasarcophaga orgyrostama,(B) Dermestes maculates,(C) Dermestes frischi and (D) Saprinus sp.
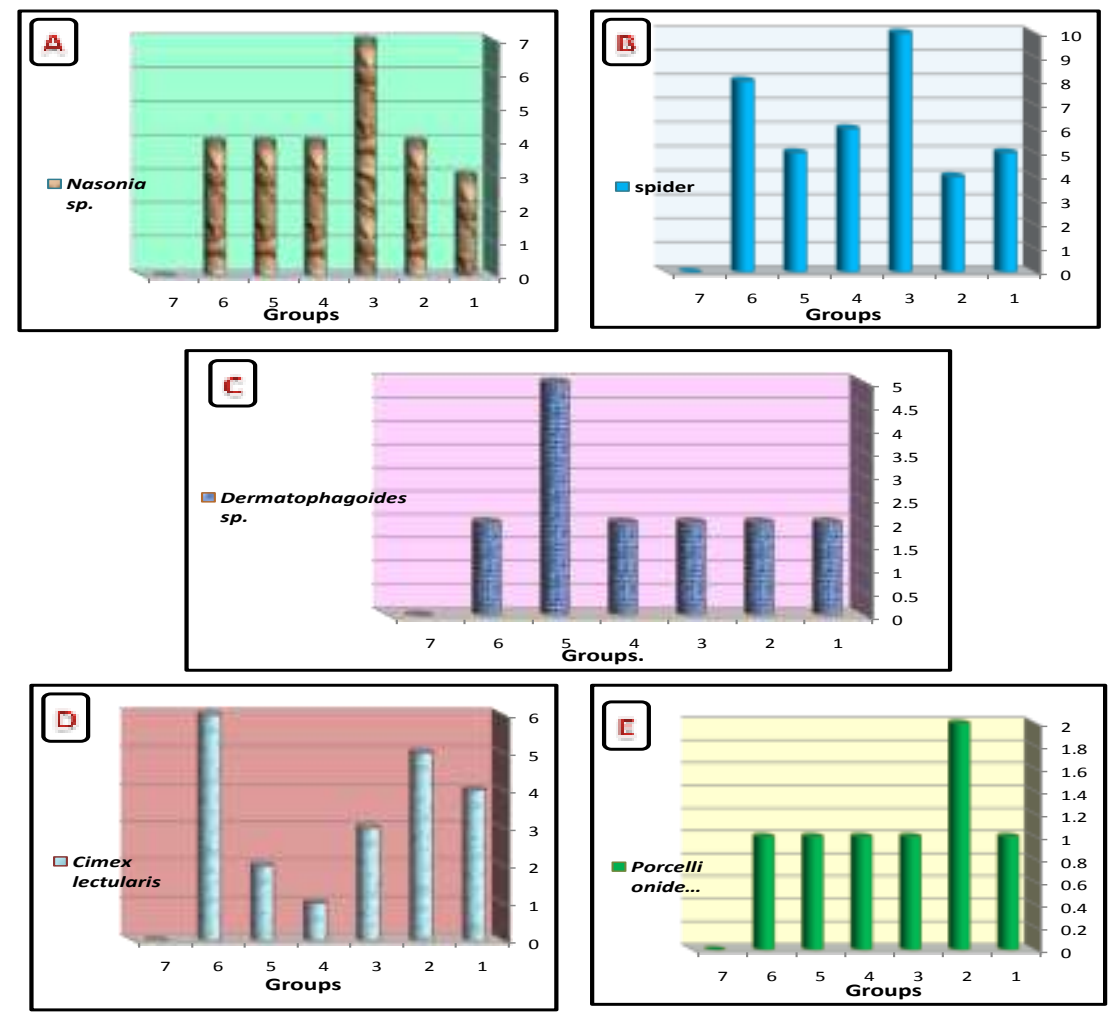

Fig.(6) : Number of arthropods from rat carrions in all seven groups, (A) Nasonia sp., (B) spider,( C) Dermatophagoides sp., (D) Cimex lectularis and (E) Porcellionides pruinosus. 


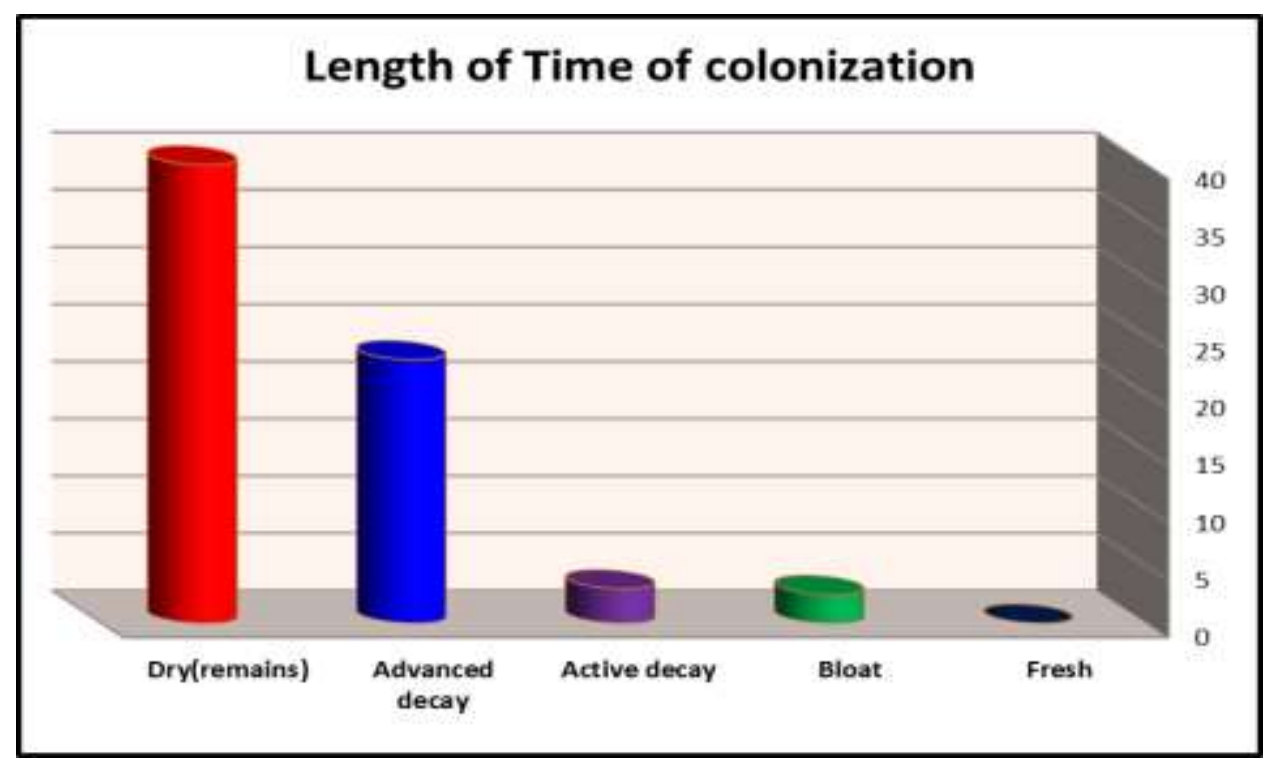

Fig. (7) : Length of time of colonization estimate by stages of decomposition.

\section{DISCUSSION}

The present results indicated that the arthropods species of forensic importance and represented by the thirteen taxa belong to phylum Arthropoda and 10 families, Family: Calliphoridae represented by Chrysomya albiceps (5\%), Family: Muscidae represented by Musca domestica (33\%), Family: Sarcophagidae represented by Sarcophaga sp. (23\%), Wohlfahrtia magnifica (22 \%) and Parasarcophaga orgyrostama (2\%), Family: Dermestidae represented by Dermestes maculates (1\%) and Dermestes frischi (1\%), Family: Histeridae represented by Saprinus sp. (4\%), Family: Pteromalidae represented by Nasonia sp. (2 \%), Family: Lycosidae represented by spider( 3\%), Family: Pyroglyphidae represented by Dermatophagoides sp. (1 \%), Family: Cimicidae represented by Cimex lectularis (2\%)and Family: Porcellionidae represented by Porcellionides pruinosus (1\%), while Aly et al (2017) indicated that the maximum number of forensic species was represented by the dipterous insects 18 species on rabbits, Aly et al. ( 2013) also observed 7 families and 10 arthropod species from rabbits and rats, Yassa et al.(2014) listed six species of insect and Valdes-Perezgasga et al.(2010) mentioned the nineteen species of Arthropods on Pig in Mexico.

In the present investigation decomposition is divided into five stages. Similar observations were also reported by Valdes-Perezgasga et al.(2010) and Aly et al( 2013) with slight modifications.

No doubt that good environmental conditions of Egypt suitable for increasing the richness of arthropods. likewise, (Goddard \& De Shazo , 2009 and Steen et al.,2004) who reveled Cimex lectularius is more prevalent in temperate climates. Aerated environment and exposure to sun reduce the time of development insects this agree with ( Greenberg et al., 2002). Temperature and access for arthropods to the body is most important affecting the decomposition of the body (Mann et al. 1990).

Mites were collected from the early stages of decomposition and the remains of corpses, this result is in accordance with the previous succession studies (Battan, et al.,2005, Camacho, 2005and Magaa, 2001), which feed on the skin flakes (Frost et al.2010). González et al.(2013) concluded that the mites feed on corpses in the early stages of decomposition and feed on dry skin in the later stages of decomposition. 
Spiders, Cimex lectularis and Porcellionides pruinosus which use the corpse as an extension of their environment this agree with the investigated by (Joseph et al,2011).

In the present study families: Calliphoridae, Muscidae and Sarcophagidae were found flying around carrions, on the other hand Whitworth (2006) showed the family Sacrophagidae generally arrived at a corpse next to Calliphoridae. Several studies in other regions where Calliphoridae (Watson \& Carlton,2003 and Sharanowski et al., 2008) and Sarcophagidae (Watson \& Carlton,2003 and De Barros et al.,2008) have been mentioned as most important colonizers of carrion.

In the present result beetles found on the carrions from bloat stage until dry or remains stage, this result is supported by the point of view of Midgley et al.(2010) where they indicated that beetles are the largest of the insect orders and are extremely adaptive and can be found in almost all environments, beetles found on the corpse when it is more decomposed or advanced decay stage. Beetles they are one of the most diverse macroinvertebrate groups and occur on all continents except Antarctica (Bilton et al, 2019).

During the first 29 days after death, biomass loss noticeably. Tissue severely putrefied and water loss during the first four decomposition stages and arthropod colonization. This result is in accordance with the previous succession studies where disturbed and undisturbed rat (De Jong \& Hoback , 2006) and rabbit carcasses (Adlam $\&$ Simmons ,2007).So, according to the type of carrion, habitat and region, arthropoda species and decomposition times were specific.

Conclusion: The present investigation revealed, the first arthropods arrival time as well as the species of arthropods and its relation to the stages of decomposition were determined. The presence of arthropods was checked at the regular intervals during the period of experiment. The arthropods of forensic importance, represented by the thirteen taxa belong to phylum arthropoda and 10 families.

\section{REFERENCES}

Abd El-Aziz, F.A., 2018. Morphological Characterization of Arthropod Ectoparasites by Scanning Electron Microscopy. Egypt. Acad. J. Biolog. Sci., 10(1): 93- 104.

Adlam, R.E.\& Simmons, T.,2007. The effect of repeated physical disturbance on soft tissue decomposition-are taphonomic studies an accurate reflection of decomposition? J Forensic Sci;52:1007-14.

Aly, M.Z.Y. ,Osman, K.S.M., Galal, F.H.\& Ali,G.H.M.,2017. Comparative Study on Outdoor and Indoor Forensic Insects encountered on Rabbit Corpses in Upper Egypt. IOSR Journal of Pharmacy and Biological Sciences (IOSR-JPBS),(12), Issue 3 Ver.: 41-54.

Aly, S.M. , Jifang , W.Xiang , W., Jifeng,C. , Qinlai1,L. \&, Ming, Z., 2013. Identification of forensically important arthropods on exposed remains during summer season in northeastern Egypt. J Cent South Univ (Med Sci) ,38(1).

Amendt J, Krettek R, \& Zehner R., 2004. Forensic entomology. Naturwissenschaften. 91:51-65.

Battan, H.M., Arnaldos, M.I., Rosso, B., \& Garcia, M.D.,2005. Estudio preliminar de la comunidad sarcosaprofaga en Cordoba (Argentina): aplicacion de la entomologia forense. Anales de Biologia;27:191-201.

Benecke. M. ,2004. Forensic entomology: arthropods and corpses. In: Tsokos M (ed) Forensic pathology reviews, vol II. Humana, Totowa, NJ, 207-240.

Bilton, D.T., Ignacio R. \& Andrew E. Z. S.,2019. Water Beetles as Models in Ecology and Evolution. Annual Review of Entomology. 64:359-377. 
Byrd J.H.\& Castner J.L. 2009. Forensic entomology: the utility of arthropods in legal investigations[M]. Boca Raton: CRC.

Camacho, G.P.C., 2005. Sucesion de la entomofauna cadaverica y ciclo vital de Calliphora vicina (Diptera: Callphoridae) como primera especie colonizadora, utilizando cerdo blanco (Sus scrofa) en Bogota. Rev Colombiana de Entomol;31:189-97.

De Barros, R.M., Mello-Patiu, C.A.\& Pujol-Luz, J.R., 2008. Sarcophagidae (Insecta, Diptera) associados _ decomposi $1 \frac{1}{4} / 40$ de carcalas de Sus scrofa Linnaeus (Suidae) em _rea de Cerrado do Distrito Federal, Brasil. Revista Brasileira de Entomologia 2008;52:606-9.

De Jong G.D. \& Hoback ,W.W., 2006. Effect of investigator disturbance in experimental forensic entomology: succession and community composition. Med Vet Entomol;20:248-58.

Frost C. L., Henk R. B., Jens A., and Alejandra P. M. 2010. Indoor Arthropods of Forensic Importance: Insects Associated with Indoor Decomposition and Mites as Indoor Markers .Current Concepts in Forensic Entomology. 93-108.

Goddard, J., \& De Shazo, R., 2009. Bedbugs (Cimex lectularius) and clinical consequences of their bites. JAMA. Apr 1;301(13):1358-66.

González M.A., González Herrera L, Perotti MA, Jiménez Ríos G.,2013. Occurrence of Poecilochirus austroasiaticus (Acari: Parasitidae) in forensic autopsies and its application on postmortem interval estimation. Exp. Appl. Acarol. 59 (3): 297305.

Greenberg, Bernard, and John C. K. , 2002. Entomology and the Law. United Kingdom: Cambridge University Press.

Gurafi, L.M.A. \& Mohamed E.A.E., 2012. Decomposition and arthropod Succession on two monkeys (Ccercopithecus aethiopicus). S.J.S.; 5:1-7.

James, L.C., 2004. Ultimate Guide to Forensic Entomology: A Review of Forensic Identification Cards.

Joseph, I., Deepu, G., Mathew, P., Sathyan, \& Geetha V.,G.,2011. The use of insects in forensic investigations: An overview on the scope of forensic entomology. $\mathrm{J}$ Forensic Dent Sci. 3(2): 89-91.

Magaa, A. C., 2001. La entomologia forense y su aplicacion a la medicina legal. Data de la muerte. Bol SEA;28:49-57.

Mann, R.W., Bass, W.M. \& Meadows, L., 1990. Time since death and decomposition of the human-body Variables and observations in case and experimental field studies. J Forensic Sci 35:103-111.

Matuszewski S., Bajerlein D. \& Konwerski S, 2008. An initial study of insect succession and carrion decomposition in various forest habitats of Central Europe[ J]. Forensic Sci Int, 180(2/3): 61-69.

Midgley, J,M., Richards C.S., Villet M.H., 2010. The utility of Coleoptera in forensic investigations. In: Amendt J, Campobasso CP, Goff ML, Grassberger M, eds. Current concepts in forensic entomology. Heidelberg: Springer, 57-68.

Nyasha, M., Ron, M. \& Gilbert, M., 2014. An initial study of insect succession on decomposing rabbit carrions in Harare, Zimbabwe. Asian Pac. J. Trop. Biomed. 4(7):561- 565.

Ødegaard, F. ,2000. How many species of arthropods? Erwin's estimate revised. Biological Journal of the Linnean Society, 71 (4): 583-597.

Ortega-Hernández, J.,2016.Making sense of 'lower' and 'upper' stem-group Euarthropoda, with comments on the strict use of the name Arthropoda von Siebold, 1848. Biol. Rev.(91), 255 - 273. 
Padonou, G. G., Gnanguenon, V., Razaki, O., Olivier O., Esdras O., Bruno A.\& Martin A., 2017. First evidence of forensic entomology revealed the presence of arthropods on rabbit carrion in Cotonou, Benin (West Africa). International Journal of Entomology Research. 2( 6): 94-98.

Schultz, C.B., Nick M. H., Erica H. \& Elizabeth E. C.,2019. Movement and Demography of At-Risk Butterflies: Building Blocks for Conservation. Annual Review of Entomology. 64:167-184.

Sharanowski B.J., Walker, E.G. \& Anderson, G.S., 2008. Insect succession and decomposition patterns on shaded and sunlit carrion in Saskatchewan in three different seasons. Forensic Sci Int;179:219-40.

Smith, M. R., 2014. Hallucigenia's onychophoran-like claws and the case for Tactopoda. Nature. 514 (7522): 363-366.

Steen, C.J., Carbonaro, P.A. \& Schwartz ,R.A. 2004.Arthropods in dermatology. J Am Acad Dermatol;50:819-842.

Thompson, J. N. ,1994.The Coevolutionary Process, University of Chicago Press, , ISBN 0-226-79760-0 , 9.

Triplehorn ,C.A. \& Johnson, N.F. ,2004. Borror and DeLong's introduction to the study of insects. Thomson Brooks/Cole, Belmont, 888.

Valdes-Perezgasga, T., Sanchez-Ramos, F.J., Garcia-Martinez, O. and. Anderson,G.S.,2010.Arthropods of Forensic Importance on Pig Carrion in the Coahuilan Semidesert, Mexico. J Forensic Sci, , 55, 4.

Watson, E.J. \& Carlton, C.E., 2003. Spring succession of necrophilous insects on wildlife carcasses in Louisiana. J Med Entomol;40:338-47.

Whitworth, T., 2006. Keys to Genera and Species of Blow Flies of America North of Mexico. Proceedings of the Entomological Society of Washington. 108 (3): 710.

Yadav, P.K., Shafiya, I.R., Padma, N. P., Dinesh, K., Rakesh, K. \& Saroj, K. 2017. Recent trends in control of ectoparasites: A review. Journal of Entomology and Zoology Studies, 5(2): 808-813.

Yassa, H.A., George, S.M. and Yones,D.A.,2014.Effect of corrosives and partial burn on the insects succession and decay of buried cadaver in different types of soil.Mansoura J. Forensic Med.Clin.Toxicol,XXII,2.

Zar,M.S. and Huang,M., 2018.Correlation of Insects with Forensic Sciences. Trends in Insect Molecular Biology and Biotechnology. 317-329. 


\section{ARABIC SUMMERY}

تأثير مفصليات الأرجل على تحلل جيف الجرذان في بيئة هوائية في فصل الربيع بأسيوط ، مصر

فاطمة الزهراء عبد الحميد عبد العزيز 1* ، دعاء محمد عبد الرحمن الشهابي2

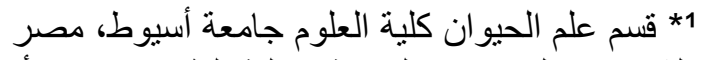

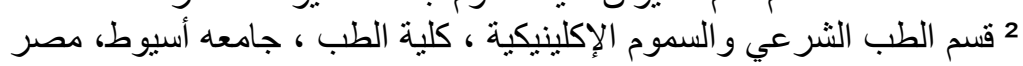

تعتبر مفصليات الأرجل واحدة من أكثر الحيو انات اللافقارية انتشارا في الوصول إلى الجيف واستعمار ها.

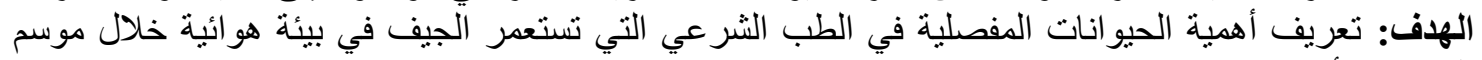

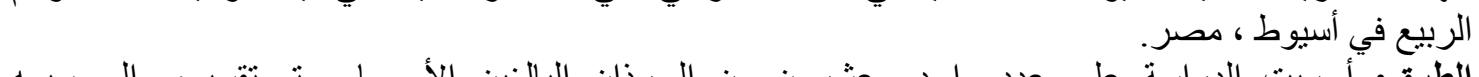

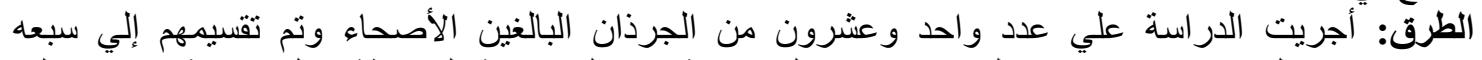

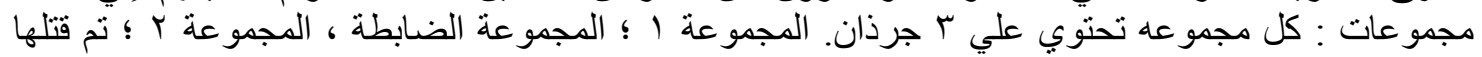

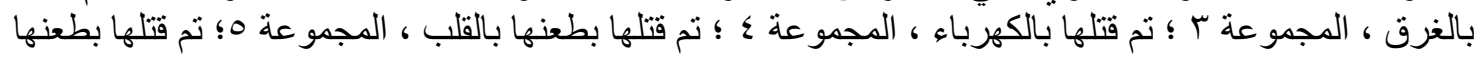

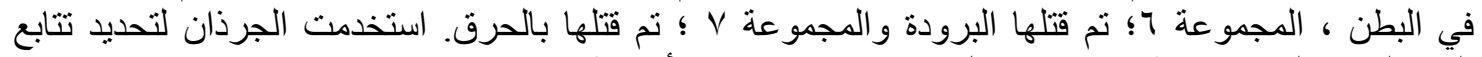

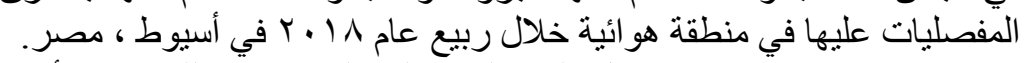

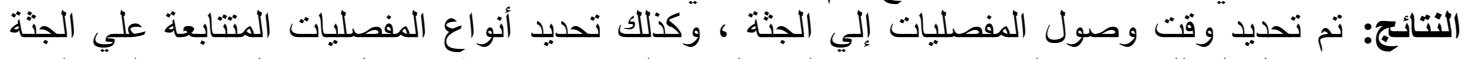

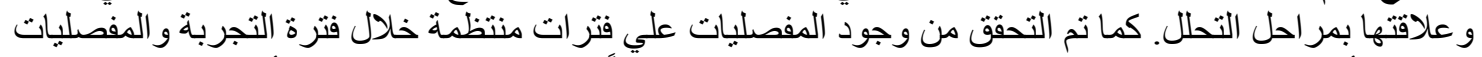

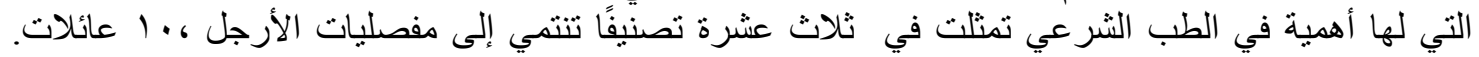

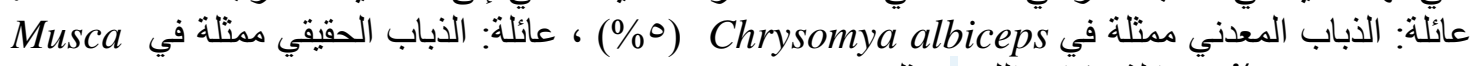

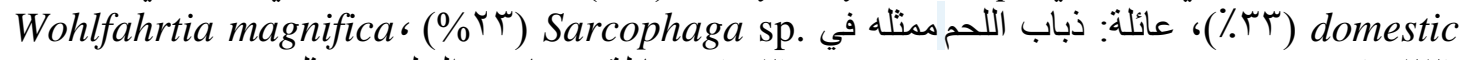

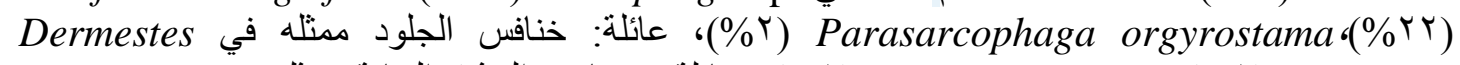

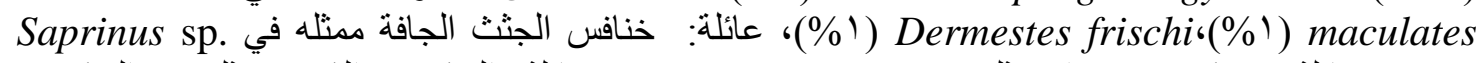

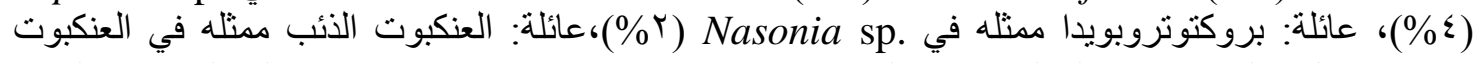

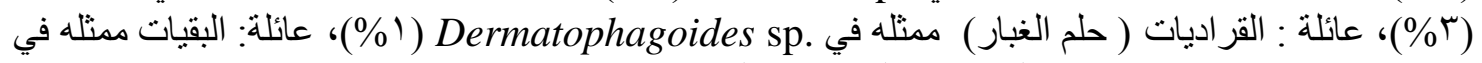
إ) Cimex lectularis

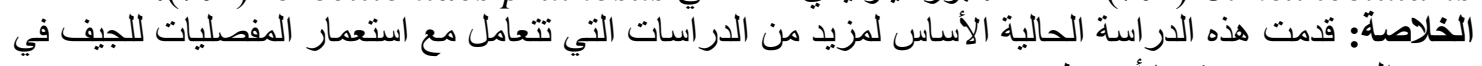

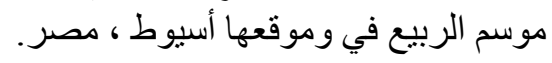

